\title{
Rainwater Storage Tank Sizing using Raincycle Model: Case Studies of a Residential, Office and Hospital Blocks
}

\author{
${ }^{1}$ Omolara Lade, ${ }^{2}$ David Oloke \\ ${ }^{1}$ Department of Civil Engineering, University of Ibadan, Nigeria \\ ${ }^{2}$ Faculty of Science and Engineering, University of Wolverhampton, United Kingdom
}

\begin{abstract}
Surface and groundwater extraction has been used to satisfy the rising demand of water in developing countries which is unsustainable. Rainwater harvesting systems is progressively becoming a sustainable water management measure. However, an assessment of their feasibility in small and large buildings is required for considerable investment cost and payback periods. In this study, Raincycle model was used to describe and analyse the different criteria for sizing a rainwater harvesting system. Raincycle model was used to size the storage tank, cost savings of tanks and choose optimum size. Behavioural (or simulation) analysis was included to compute the changes in storage content of a finite reservoir. To apply this method, three case studies were used: a residential apartment, office and hospital blocks. Result reveals a tank size of $4 \mathrm{~m}^{3}, 10 \mathrm{~m}^{3}$ and $12 \mathrm{~m}^{3}$ could meet the maximum percentage of demand and predicted to save $\$ 259, \$ 2,564$, and $\$ 51,072$ over 50 years for case studies 1, 2 and 3 respectively. A payback period of 21 years, 8 years and 1 year was recorded for the three case studies, respectively. This study also shows that the implementation of a rainwater harvesting system in a residential dwelling is not a feasible investment in terms of economic savings as it presents payback time that is not feasible. The office and hospital blocks present a payback time that is considered feasible as payback time is reached during the building's lifetime.
\end{abstract}

Keywords: Sustainable water use, Rainwater harvesting, Tank sizing, Economical assessment, Payback time.

\section{INTRODUCTION}

The world is suffering from severe water scarcity issues as water supply networks are under stresses in many cities [12]. Sustainable water use and guaranteed quantity and quality for future generations can be achieved through reduction in demand whilst increasing the efficiency of water use. Rainwater harvesting (RWH) is a technology that should be a precaution for upcoming scarcity situations through reduction in potable water consumption [3].

Rainwater harvesting system (RWHS) have been used in many countries of the world to strengthen urban stormwater management and simultaneously reduce municipal water supply stress and restores natural water cycles in urban areas [4-8]. RWH has been explored globally to reduce potable water consumption. The use of RWHS in a household as led to a savings of up to $40 \%$ of potable water use [9]. A research conducted in United Kingdom shows that 36-46 \% of WC demand can be met, resulting in a payback period of 23 and 7 years respectively [10]. In Sweden, a study in a residential area revealed a saving of more than $60 \%$ can be achieved when rainwater is used for WC flushing. In Brazil, the potential for potable water savings was evaluated through use of rainwater for washing vehicles in petrol stations [11].

The design of RWHS has been evaluated using numerous modelling tools and methods including the design of storm approach [12]. The most common approach is long-term continuous simulations which can be used to evaluate the effectiveness of both stormwater management and monetary benefits of RWHS [13-16] and to determine the optimal tank size [17-18]. However, these modelling tools are limited, as a few could be used to assess the water saving and stormwater potential as well as the economic feasibility of RWHS.

A rainwater tank can be considered as a storage reservoir that receives stochastic inflows (effective runoff) over time and is sized to satisfy system demands [19]. The designer controls the tank size, hence some techniques to determine the size that will provide the optimum level of service is required [20]. In another study, the sizing of storage reservoirs was reviewed to identify two general categories of sizing techniques: Moran related methods and critical period methods [21].

Behavioural analysis is a technique more suited to the study; it has several advantages compared to the Moran related and mass curve methods. Numerous researchers investigating RWHS performance have used the technique [22-24]. Several monitoring studies have confirmed the validity of behavioural models [25]. A domestic RWHS installed in a UK property, which was used for WC flushing, was modelled [26]. A behavioural model of the system was created and compared with data collected from the RWHS over 12-months. The actual system performance was accorded with predicted 
ISSN (online): 2581-3048

Volume 4, Issue 11, pp 11-19, November-2020 https://doi.org/10.47001/IRJIET/2020.411002

behaviour and this provides empirical validation of a behavioural approach in a domestic UK context.

This study aims to determine the best criteria to size rainwater storage tank when "behavioural approach" is used. Three case studies were used: a residential apartment, an office block and a hospital block. The results for each case study, such as the tank size and parameters related to the systems performance and the economic feasibility are presented and analysed.

\section{CASE STUDIES}

\subsection{Residential apartment}

Case Study 1 is a semi-detached twin bungalow for 12 occupants in Ibadan North Local Government of Oyo State, Nigeria. Table 1presents the summary of parameters input into the model.

Catchment surface area $=196 \mathrm{~m}^{2}$

Water demand: Above average $=258 \mathrm{~m}^{3} / \mathrm{yr}$

Average $=214 \mathrm{~m}^{3} / \mathrm{yr}$

Below average $=171 \mathrm{~m}^{3} / \mathrm{yr}$

Below average $=3,135 \mathrm{~m}^{3} / \mathrm{yr}$

\section{METHODS}

For the three case studies presented, Raincycle model was used to size the storage tank, cost savings of tanks and choose optimum size. Behavioural (or simulation) analysis was included [21] to compute the changes in storage content of a finite reservoir (one that can overflow and empty) using the water balance equation shown in equation 1[27].

$$
\mathrm{V}_{\mathrm{t}}=\mathrm{V}_{\mathrm{t}-1}+\mathrm{Q}_{\mathrm{t}}-\mathrm{D}_{\mathrm{t}}-\Delta \mathrm{E}_{\mathrm{t}}-\mathrm{L}_{\mathrm{t}}
$$

Subject to $0 \leq \mathrm{V}_{\mathrm{t}} \leq \mathrm{S}$

Where:

$\mathrm{V}_{\mathrm{t}} \quad=$ storage content at time $\mathrm{t}\left(\mathrm{m}^{3}\right)$.

$\mathrm{V}_{\mathrm{t}-1} \quad=$ storage content at time $\mathrm{t}-1\left(\mathrm{~m}^{3}\right)$.

$\mathrm{Q}_{\mathrm{t}} \quad=$ flow into the reservoir during time interval $\left(\mathrm{m}^{3}\right)$.

$\mathrm{D}_{\mathrm{t}} \quad=$ controlled release during time interval $\mathrm{t}\left(\mathrm{m}^{3}\right)$.

$\Delta \mathrm{E}_{\mathrm{t}}=$ net evaporation loss from the reservoir during time interval $\mathrm{t}\left(\mathrm{m}^{3}\right)$.

$\mathrm{L}_{\mathrm{t}} \quad=$ other losses during time interval $\mathrm{t}$, e.g. seepage $\left(\mathrm{m}^{3}\right)$.

$\mathrm{S} \quad=$ active reservoir capacity $\left(\mathrm{m}^{3}\right)$.

Table 1: Data input - summary of parameter values

\begin{tabular}{|c|l|l|}
\hline Module & \multicolumn{1}{|c|}{ Item } & \multicolumn{1}{c|}{ Value } \\
\hline \multirow{2}{*}{ Rainfall } & Above average rainfall & $1,639 \mathrm{~mm} / \mathrm{yr}$ \\
profiles & Average rainfall & $1,311 \mathrm{~mm} / \mathrm{yr}$ \\
& Below average rainfall & $983 \mathrm{~mm} / \mathrm{yr}$ \\
\hline \multirow{2}{*}{ Catchment } & High runoff coefficient & 0.90 \\
surface & Expected runoff coefficient & 0.85 \\
& Low runoff coefficient & 0.75 \\
\hline \multirow{2}{*}{ Rainwater } & High filter coefficient & 0.92 \\
filter & Expected filter coefficient & 0.90 \\
& Low filter coefficient & 0.85 \\
\hline
\end{tabular}

\subsection{Office block}

Case study 2 is Dr Egbogah's building in the Department of Civil Engineering, University of Ibadan, Nigeria.

Catchment surface area $=566 \mathrm{~m}^{2}$

Water demand: Above average $=458 \mathrm{~m}^{3} / \mathrm{yr}$

Average $=441 \mathrm{~m}^{3} / \mathrm{yr}$

Below average $=396 \mathrm{~m}^{3} / \mathrm{yr}$

\subsection{Hospital ward}

Case study 3 is Otunba-tunwase Children Outpatient Ward, University College Hospital, Ibadan, Nigeria

Catchment surface area $=8,132 \mathrm{~m}^{2}$

Water demand: Above average $=4,704 \mathrm{~m}^{3} / \mathrm{yr}$

Average $=3,920 \mathrm{~m}^{3} / \mathrm{yr}$

The most used storage device with regards to contemporary RWHS is the underground tank [28]. These are watertight and airtight, so the net evaporation loss term $\Delta \mathrm{E}_{\mathrm{t}}$, and the other losses term $\mathrm{L}_{t}$ can be ignored [29]. Equation 1 then becomes:

$$
\mathrm{V}_{\mathrm{t}}=\mathrm{V}_{\mathrm{t}-1}+\mathrm{Q}_{\mathrm{t}}-\mathrm{D}_{\mathrm{t}}
$$

Subject to $0 \leq \mathrm{V}_{\mathrm{t}} \leq \mathrm{S}$.

At the end of a prescribed time interval, the water in storage is equal to the volume of water remaining in storage from the previous interval, plus any inflow and less any demand during the time period, provided that the computed volume in store does not exceed slope capacity. Behavioural models thus simulate the operation of a reservoir with respect to time by routing simulated mass flows through an algorithm describing reservoir operation [19].

The generalised YAS/YBS algorithm was incorporated into the RainCycle model adopted in this study, with the storage operating parameter $\theta$ set to zero (YAS) as the default mode of operation. It is acknowledged that a more conservative prediction of system performance would have been achieved with the use of YAS setting than use of YBS. However, research suggested that as long as certain constraints regarding the selected time-step are employed, then YAS models are capable of modelling system performance within $\pm 10 \%$ of that predicted by a more accurate hourly time-step 
ISSN (online): 2581-3048

Volume 4, Issue 11, pp 11-19, November-2020

https://doi.org/10.47001/IRJIET/2020.411002

model and this was considered to be an acceptable margin of error [30].

\subsection{Rainfall data used in the adopted RainCycle model}

The RainCycle model operates on a daily time-step, and so it requires historic rainfall data with the same temporal scale. It was suggested that a minimum of 10 years' worth of precipitation records should be used [31]. Since the study is primarily concerned with analysing domestic RWHS in Ibadan, the selection criteria with regards to the selected station was that the location should be representative of typical weather patterns in the City (i.e. the average annual rainfall depth should not significantly deviate from what would be expected for the City as a whole). A continuous 30-year daily rainfall record covering the years 1980-2009 was obtained from Department of Meteorological Station (DMS) Samonda and the International Institute of Tropical Agriculture (IITA), Ibadan. Figure 1shows annual rainfall depths contained within the data set. Note the extreme marked on the graph, which correspond to the 1980 floods, which affected much of Ibadan.

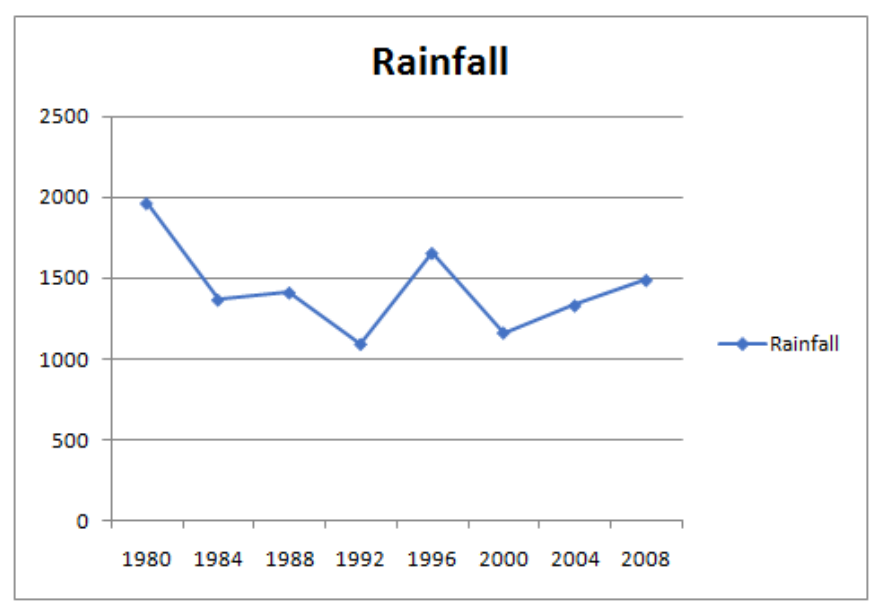

Figure 1: Ibadan City historic annual rainfall depths 1980-2009 (source:[32])

\subsection{Predicting non-potable domestic demand}

Per capita consumption varies with household size, type of property, time of the year and ages of household residents [33]. Increases in household demand are primarily driven by population growth, levels of affluence and household occupancy [34]. In modern developments, the UK Code for Sustainable Homes Standard [35] may act as a significant driver for reduction in domestic water use. To achieve the lowest level of compliance, a minimum per capita consumption of 120 litres per day is required for internal water use and this may come to represent the minimum standard for new housing stock.
About $55 \%$ of total household demand could be met through domestic RWHS, if used for non-potable applications, such as WC flushing, laundry washing and garden irrigation. Demand forecasting based on rules of thumb or naive extrapolation is now recognized as inappropriate since estimates obtained this way deviate from reality [36]. A micro-component approach to water demand forecasting is often recommended [34]: that is the study of individual water usage within a household, such as personal washing and WC flushing [33]. Numerous studies have used this approach in predicting future demand [34, 37-38]. However, regarding future water demand, no definite conclusion can be drawn [39], only more or less reasoned and transparent investigations [40]. Considering climate change, assumption that washing machine and WC use are insensitive to long-term variations can be made [39-40].

\subsection{Water closet demand}

There is no cause to believe that WC usage frequency will increase or decrease significantly, and so existing data based on past monitoring studies was used as an acceptable indicator of future behaviour. The mean of the values equal to 4.59 flushes per person per day. However, it is impossible to flush a toilet 4.59 times, so a per capita usage of 4times/day was assumed for weekday (Monday-Friday), whilst a per capita usage of 6times/day was assumed for weekends (Saturday and Sunday). This assumes higher weekend usage, which is reasonable, and gives mean rate of 4.57/person/day, which is close to the actual average of 4.59. An essentially linear relationship was found between household occupancy and frequency of WC flushes [41]. Therefore, an acceptable approach for calculating household usage is to multiply the household occupancy rate by the capita usage frequency. In the current regulations, a maximum flush volume of 6 litres is permitted for single-flush WCs [42]. Dual-flush toilets ranging from $6 / 4,6 / 3$, as well as lower volume single flushes, such as 4.5 litres, is available.

To demonstrate the technical lower limit for flush volumes, the last three items were included. But there is no sign of widespread implementation of these methods in the short to medium term. The flush volumes ranging from 6-litre single to 4/2-litre dual were chosen. An assumption of 6/3 dual flush variety was decided for all new houses. There is also the issue of how many uses will involve a full flush and how much only a part flush. It was reported that an assumption of $1: 3$ or $1: 4$ is made for the ratio of full to part flush, whilst monitoring trials have shown the actual flush ratio to be in the range of 1:0 (i.e. only full flush used) and 1:2 (1 full to 2 part flushes) [43]. A full flush ratio of 1:2 was been adopted in the RainCycle model. 
ISSN (online): 2581-3048

Volume 4, Issue 11, pp 11-19, November-2020 https://doi.org/10.47001/IRJIET/2020.411002

\subsection{Washing machine demand}

A range of washing machine (WM) use frequencies is shown in Table 2. Anticipated future per capita use frequencies will probably not differ much from those occurring at present. The mean of domestic washing machine frequencies is 0.21 uses per person per day ( once every 5 days). This latter figure was used as a standard value for domestic simulations. This is a general relationship between frequency of WM usage and household occupancy [41]. Thus, to determine household usage the per capita frequency can simply be multiplied by the household occupancy rate.

Table 2: Range of domestic washing machine usage frequencies

\begin{tabular}{|ll|}
\hline Uses/person/day & References \\
\hline 0.16 & {$[41]$} \\
\hline 0.18 & {$[44]$} \\
\hline 0.157 & {$[34]$} \\
\hline 0.34 & {$[35]$} \\
\hline 0.21 & Mean \\
\hline
\end{tabular}

\section{RESULTS AND DISCUSSIONS}

The Raincycle advanced analysis process is used to determine range of suitable tank sizes, cost savings of tanks and choose optimum size (Figures 2 and 3).

\subsection{Residential apartment}

Optimising tank size results reveals that a tank size of 4 $\mathrm{m}^{3}$ could meet the maximum percentage of demand. Optimise saving analysis showed that there were four tank sizes with a potential long-term profit. The best was $4 \mathrm{~m}^{3}$ tank which was predicted to save $\$ 259$ over 50 years and had a payback period of 21 years.

The $4 \mathrm{~m}^{3}$ gave acceptable results and so the data for this tank was input into the storage tank module (tank size) and Whole Life Cost (WLC) details module (capital costs) and then the result in the analysis system module were examined. Figures 4 and 5 show the cost comparison graphs for both the long-term and average per-year analyses for this system.

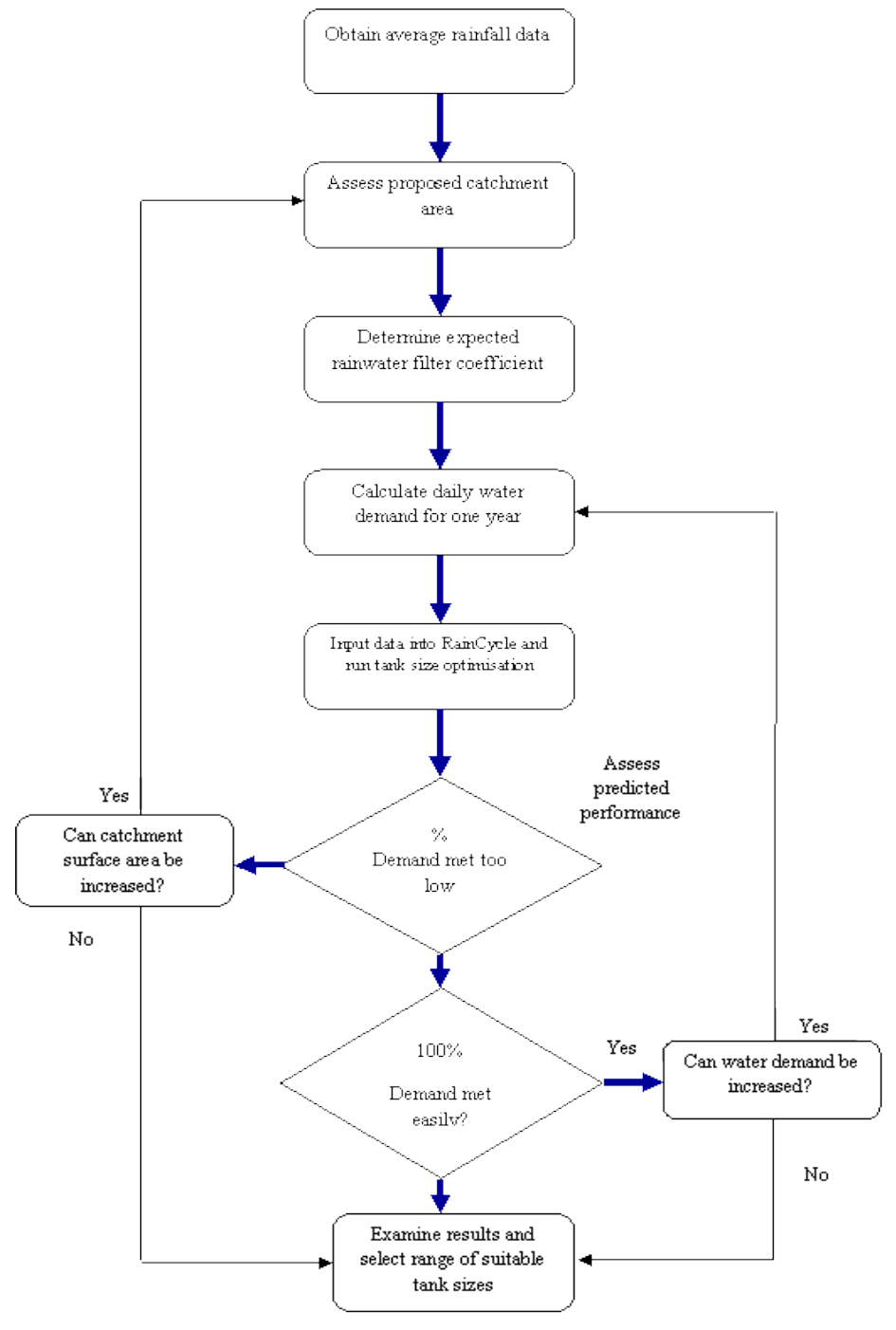

Figure 2: Determining range of suitable tank sizes 


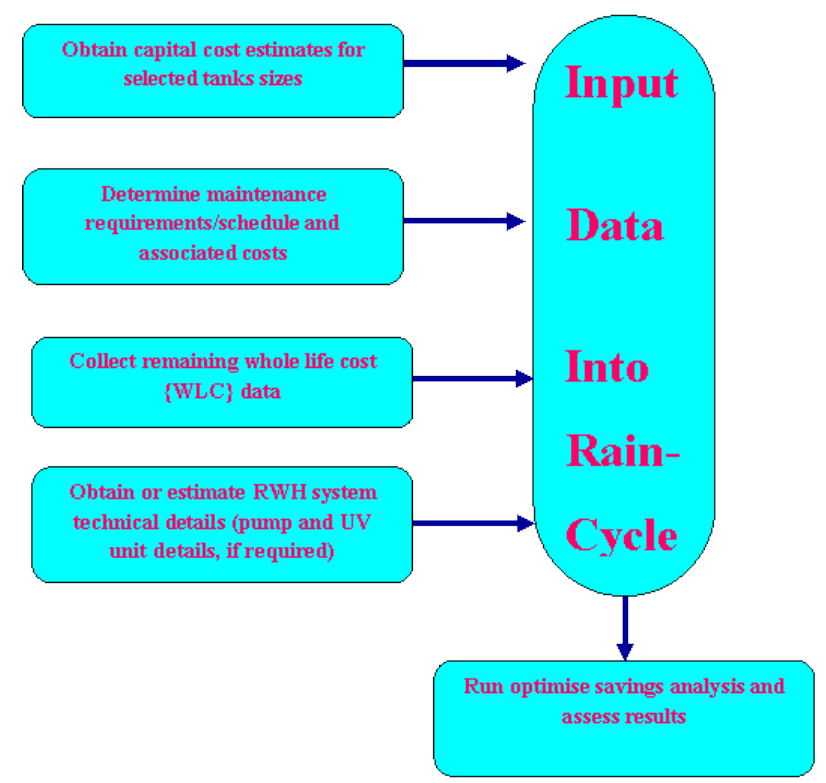

Figure 3: Determining cost savings of tanks and choosing optimum size
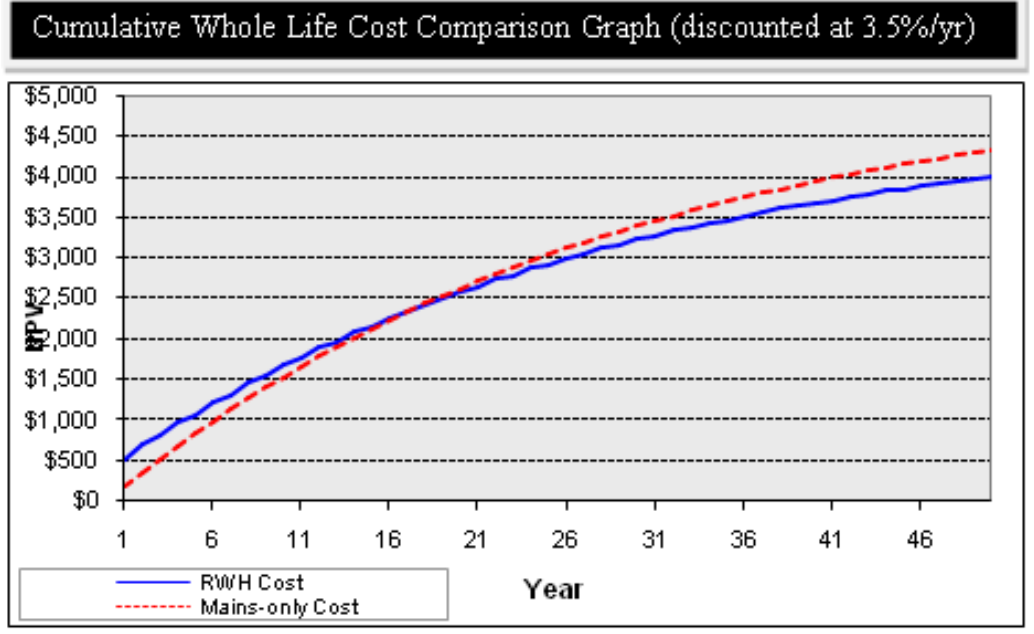

Figure 4: Cumulative long-term analysis cost comparison (residential)

\section{Average Vearly Cost Comparison Graph (discounted - 3.5\%)}

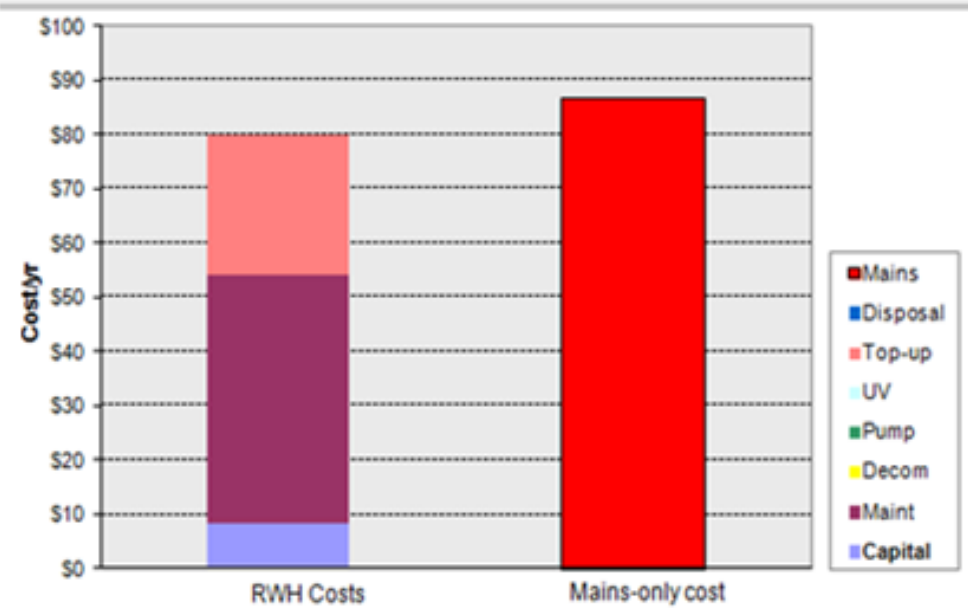

Figure 5: Average yearly cost comparison (residential) 
ISSN (online): 2581-3048

Volume 4, Issue 11, pp 11-19, November-2020

https://doi.org/10.47001/IRJIET/2020.411002

\subsection{Office block}

Optimise tank size results reveal that a tank size of $10 \mathrm{~m}^{3}$ could meet the maximum percentage of demand. Optimise saving analysis showed that there were six tank sizes with a potential long-term profit. The best was the $10 \mathrm{~m}^{3}$ tank, which was predicted to save $\$ 2,564$ over 50 years and had a payback period of 8 years.

The $10 \mathrm{~m}^{3}$ gave acceptable results and so the data for this tank was input into the Storage Tank module (tank size) and WLC Details module and then the result in the Analysis System module examined. Figures 6 and 7 show the cost comparison graphs for both the long-term and average peryear analyses for this system.

\section{Cumulative Whole Life Cost Comparison Graph (discounted at $3.5 \%$ per year)}

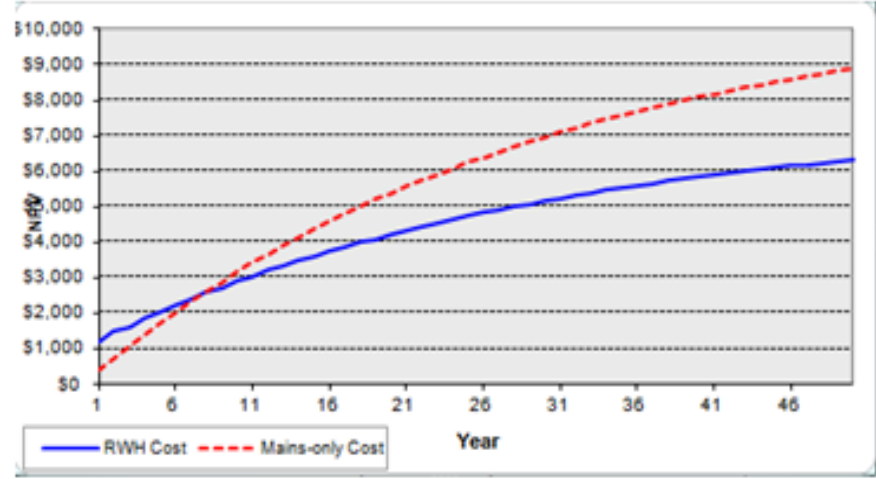

equivalent maıns-onty system over a su year penoc NPV $=$ Present Value

Figure 6: Cumulative long-term analysis cost comparison (office)

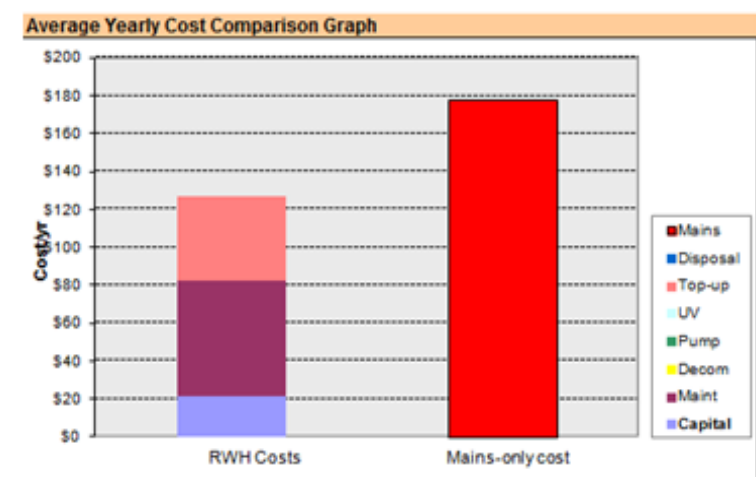

Shows the average yearly cost of supplying water from the rainwater harvesting (RWH) system as compared to an equivalent mains-only system. Average cost is calculated over 50 years and takes into account all cost activities as well as the selected discount rate of $3.5 \%$

Figure 7: Average yearly cost comparison (office)

\subsection{Hospital blocks}

Optimise tank size results reveal that a tank size of $12 \mathrm{~m}^{3}$ could meet the maximum percentage of demand. Optimise saving analysis showed that there were seven tank sizes with a potential long-term profit. The best was the $12 \mathrm{~m}^{3}$ tank, which was predicted to save $\$ 51,072$ over 50 years and had a payback period of 1 year.
The $12 \mathrm{~m}^{3}$ gave acceptable results and so the data for this tank was input into the Storage Tank module (tank size) and WLC Details module and then the result in the Analysis System module examined. Figures 8 and 9 show the cost comparison graphs for both the long-term and average peryear analyses for this system.

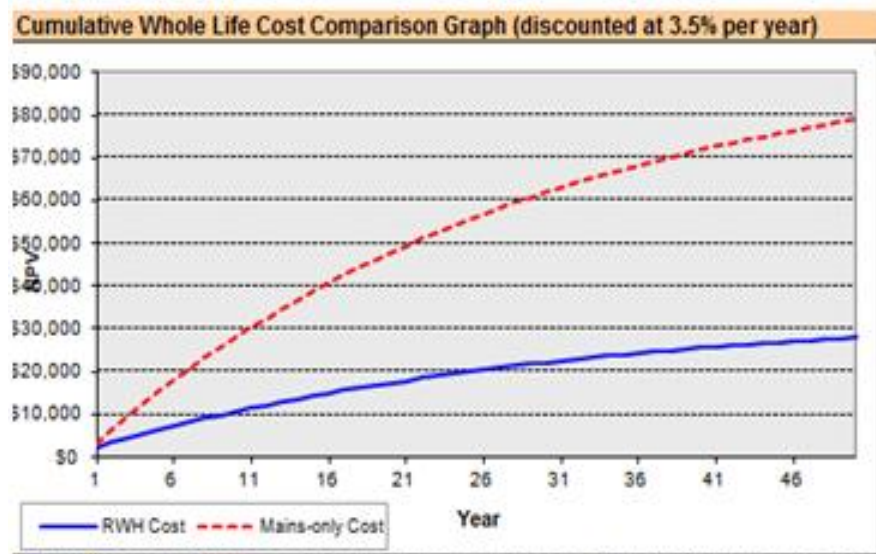

Shows the cumulative financial expenditure required for both the RWH system and an equivalent mains-only system over a 50 year period

$N P V=$ Present Value

Figure 8: Cumulative long-term analysis cost comparison (hospital)

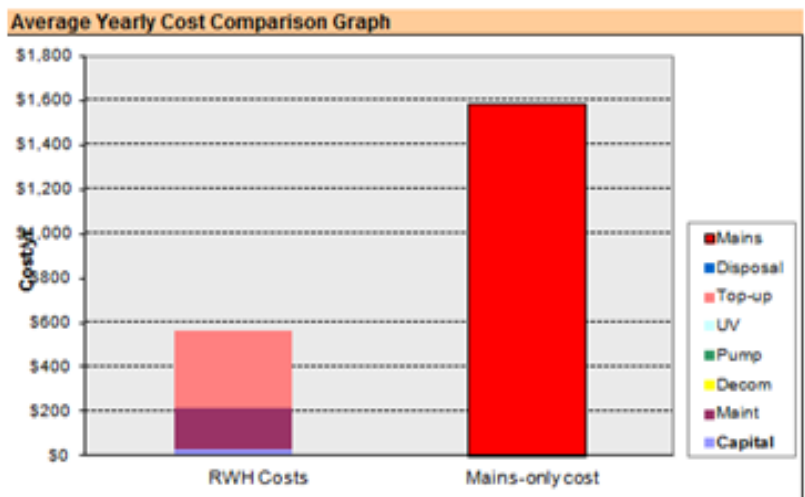

Shows the average yearly cost of supplying water from the rainwater harvesting (RWH) system as compared to an equivalent mains-only system. Average cost is calculated over 50 years and takes into account all cost activities as well as the selected discount rate of $3.5 \%$

Figure 9: Average yearly cost comparison (hospital)

\section{CONCLUSION}

This study focuses on the sizing of rainwater storage tanks using Raincycle model. The aim of this study is to determine the criteria for defining a storage volume and cost savings of tanks when a simulation is made to choose optimum size.

Three case studies were analysed to apply the defined criteria and compare the results of storage volumes and related performance and economic assessments.

Analysis of case study 1 reveals the best tank size was 4 $\mathrm{m}^{3}$ which was predicted to save $\$ 259$ over 50 years and had a payback period of 21 years. 
Analysis of case study 2 reveals the best tank size was 10 $\mathrm{m}^{3}$ which was predicted to save $\$ 2,564$ over 50 years and had a payback period of 8 years.

Analysis of case study 3 reveals the best tank size was 12 $\mathrm{m}^{3}$ predicted to save $\$ 51,072$ over 50 years and had a payback period of 1 year.

This study also shows that the implementation of a rainwater harvesting system in a residential dwelling is not a feasible investment in terms of economic savings as it presents payback time that is not feasible. The office and hospital building present a payback time that is considered feasible as payback time is reached during the building's lifetime.

\section{REFERENCES}

[1] Zhang, S., Zhang, J., Yue, T., JingX., "Impacts of climate change on urban rainwater harvesting systems", Science of the Total Environment, 665, pp. 262-274, 2019.

[2] Imteaz, M.A., Adeboye, O., Rayburg, S., Shanableh, A., "Rainwater harvesting potential for southwest Nigeria using daily water balance model", Resources, Conservation and Recycling, 62, pp. 51-55, 2012.

[3] EEA, "Towards efficient use of water resources in Europe. European Environment Agency", EEA Report No1/2012, 68 pp. Copenhagen. ISBN 978-929213-275-0, 2012.

[4] Vialle, C., Busset, G., Tanfin, L., MontrejaudVignole s, M., Huau, M.C., Sablayrolles C., "Environmental analysis of a domestic rainwater harvesting system: A case study in France", Resources, Conservation and Recycling, 102, pp. 178-184, 2015.

[5] Mehrabadi, M.H.R., Saghafian, B., Fashi, F.H., "Assessment of residential rainwater harvesting efficiency for meeting non-potable water demands in three climate conditions", Resource, Conservation and Recycling, 73, pp. 86-93, 2013.

[6] Jones, M.P., Hunt, W.F., "Performance of rainwater harvesting systems in the southeastern United States", Resources, Conservation and Recycling, 54, pp. 623-629, 2010.

[7] Kim, K., Yoo, C., "Hydrological modelling and evaluation of rainwater harvesting facilities: Case study on several rainwater harvesting facilities in Korea", Journal of Hydrologic Engineering, 14, pp. 545-561, 2009.

[8] Ghisi, E., Bressan, D.L., Martini, M., "Rainwater tank capacity and potential for potable water savings by using rainwater in the residential sector of southeastern Brazil", Journal of Building Environment, 42, pp. 1654-1666, 2007.
[9] Muthukumaran, S., Baskaran, K., Sexton, N., "Quantification of potable water savings by residential water conservation and reuse-A case study", Resources, Conservation and Recycling, 55(11), pp. 945-52, 2011.

[10] Ward, S., Memon, F.A., Butler, D., "Rainwater harvesting: model-based design evaluation", Water Science and Technology, 61(1), pp. 85-96, 2010.

[11] Ghisi, E., David a Fonseca, T., Rocha, V.L., "Rainwater harvesting in petrol stations in Brasilia: Potential for potable water savings and investment feasibility analysis", Resources Conservation and Recycling, 54 (2), pp. 79-85, 2009.

[12] Vaes, G. \&Berlamont, J., "The effect of rainwater storage tanks on design storms", Urban Water, 3, pp. 303-307, 2001.

[13] Jing, X., Zhang, S., Zhang, J., Wang, Y., Wang, Y., "Assessing efficiency and economic viability of rainwater harvesting systems for meeting non-potable water demands in four climatic zones of China", Resources, Conservation and Recycling, 126, pp. 7485, 2017.

[14] Jing, X., Zhang, S., Zhang, J., Wang, Y., Wang, Y., Yue T., "Analysis and modelling of stormwater volume control performance of rainwater harvesting systems in four climatic zones of China", Water Resources and Management, 32 (2), pp. 26492664, 2018.

[15] Hashim, H., Hudzori, A., Yusop, Z., Ho, W.S., "Simulation based programming for optimization of large-scale rainwater harvesting system: Malaysia case study", Resources, Conservation and Recycling, 80, pp. 1-9, 2013.

[16] Hajani, E., Rahman, A., "Rainwater utilization from roof catchments in arid regions: A case study for Australia", Journal of Arid Environment, 111, pp. 3541, 2014.

[17] Nápoles-Rivera, F., Rojas-Torres, M.G., Ponce Ortega, J.M., Serna-Gonzalez, M., El-Halwagi, M.M., "Optimal design of macroscopic water networks under parametric uncertainty", Journal of Cleaner Production, 88, pp. 172-184, 2015.

[18] Imteaz, M.A., Shanableh, A., Rahman, A., Ahsan, A., "Optimisation of rainwater tank design from large roofs: A case study in Melbourne, Australia", Resources, Conservation and Recycling, 55, pp. 1022-1029, 2011.

[19] Fewkes, A. "The Technology, Design and Utility of Rainwater Catchment Systems. In: Butler, D. and Memon, F.A. (Eds)", Water Demand Management. IWA Publishing. London, 2006. 
[20] Fewkes, A. "The instrumentation and field testing of a rainwater collector", Proceedings of 8th International Conference on Rainwater Catchment Systems, Tehran, Iran, April 1997.

[21] McMahon, T.A. and Mein, R.G., "Reservoir capacity and yield. In: Chow, V.T. (Ed)", Developments in Water Science, Elsevier, London, pp. 71-106, 1978.

[22] Ghisi, E., Bressan, D.L. and Martini, M., "Potential for potable water savings by using rainwater in the residential sector of south-eastern Brazil", Building and Environment, 42, pp. 1654-1666, 2007.

[23] Mitchell, V.G., "How important is the selection of computational analysis method to the accuracy of rainwater tank behaviour modelling?" Journal of Hydrological Processes, 21 (21), pp. 2850-2861, 2007.

[24] MJA, "The cost-effectiveness of rainwater tanks in urban Australia. Report prepared by Marsden Jacob Associates", The National Water Commission, Canberra, Australia, 38pp, 22 February 2007.

[25] Coombes, P.J., Argue, J.R., Kuczera, G., "Figtree Place: A case study in water sensitive urban development". Urban Water, 1(14), pp 335-343, 2000.

[26] Fewkes, A., "The use of rainwater for WC flushing: The field testing of a collection System", Building and Environment, 34, pp. 765-772, 1999.

[27] McMahon, T.A., Pegram, G.G.S., Vogel, R.M. and Peel, M.C., "Revisiting reservoir storage-yield relationship using a global stream flow database", Advances in Water Resources, 30, pp. 1858-1872, 2007.

[28] Hassell, C., "Rainwater harvesting in the UK - A solution to increasing water shortages?" Proceedings of 12th International Conference on Rainwater Catchment Systems, New Delhi, India, 6 pp, 2005.

[29] Chu, S.C., Liaw, C.H., Tsai, Y.L., Chen, J.C., Chen, J.T. and Lee, S.C., "Planning strategy study for roof rainwater catchment systems", Proceedings of 8th International Conference on Rainwater Catchment Systems, Tehran, Iran, April, pp. 383-392, 1997.

[30] Fewkes, A. and Butler, D., "Simulating the performance of rainwater collection and reuse system using behavioural models", Building Services Engineering Research and Technology, 21, pp. 99106, 2000.

[31] Gould, J. and Nissen-Peterson, E., "Rainwater Catchment Systems for Domestic Supply: Design, Construction, and Implementation" Intermediate Technology Publications, London, 335pp, 1999.

[32] DMS, "Weather Observation Station", Department of Meteorological Services, Samonda, Ibadan, 2010.
[33] Memon, F.A., Butler, D., "Water consumption trends and demand forecasting techniques", In water Demand Management, Butler D. and Memon, F.A, (eds) IWA publishing, ISBN 1843390787, 1-26, 2006.

[34] Environment Agency, "A scenario approach to water demand forecasting", National Water Demand Management Center, Environment Agency, West Sussex, UK, 2001.

[35] DCLG, "Code for sustainable homes: Technical guide" Department for Communities and Local Government, Communities and Local Government Publications, HMSO, London, 2007.

[36] Herringthon, P.R., "Water demand forecasting in OECD countries", Organisation for Economic Cooperation and Development. Environment Monograph No. 7, OECD Environmental Directorate, Paris, 1987.

[37] Williamson, P., Mitchell, G. and McDonald, A.T., "Domestic water demands forecasting: A static micro simulation approach", Water and Environment Journal, 16, pp. 243-248, 2002.

[38] Chambers, V.K., Creasey, J.D., Glennie, E.B., Kowalski, M. and Marshallsay, D., "Increasing the value of domestic water use data for demand management-summary report" WRC collaborative Project CP 187, Report no. P6805, Swindon, Wiltshire, UK, 2005.

[39] Downing, T.E., Butterfield, R.E., Edmonds, B., Knox, J.W., Moss, S., Piper, B.S. and Weather head, E.K. (and the CCDeW Project Team), "Climate change and demand for water. Final report" Stockholm Environment Institute, Oxford Office, Oxford, 201 pp, February 2003.

[40] Alegre, N., Jeffrey, P., Mclntosh, B., Thomas, J.S., Hardwick, I. and Riley, S., "Strategic options for sustainable water management at new developments: The application of a simulation model to explore potential water savings", Water, Science and Technology, 50 (2), pp. 9-15, 2004.

[41] Butler, D., "The influence of dwelling occupancy and day of the week on domestic appliance wastewater discharges", Building and Environment, 28 (1), pp. 73-79, 1991.

[42] HMSO, "Water Supply (Water Fittings) Regulations 1999. Statutory Instruments No. 1148, Water Industry", England and Wales, HMSO, London, 240pp, 1999.

[43] Grant, N., "The economics of water efficient products in the household", Environment Agency Report EA/BR/E/STD/V1, June 2003. 
[44] SODCON, "Survey of domestic consumption", In

Water Demand Management. Anglian Water, Normich, 361 pp, 1994.

\section{Citation of this Article:}

Omolara Lade, David Oloke, "Rainwater Storage Tank Sizing using Raincycle Model: Case Studies of a Residential, Office and Hospital Blocks" Published in International Research Journal of Innovations in Engineering and Technology - IRJIET, Volume 4, Issue 11, pp 11-19, November 2020. https://doi.org/10.47001/IRJIET/2020.411002 